\title{
Impact of Information Education Communication (IEC) and Knowledge of KVK Panipat Fraternity for Crop Residue Management in Periphery of District Panipat (Haryana)
}

\author{
Kushal Raj ${ }^{1 *}$, Rajbir Garg ${ }^{2}$, Dev Raj ${ }^{3}$, Sundeep Antil $^{4}$ and Satpal Singh ${ }^{5}$ \\ ${ }^{1}$ DES (Plant Pathology), Krishi Vigyan Kendra, Ujha (Panipat), \\ CCS Haryana Agricultural University, India \\ ${ }^{2}$ PES (Agronomy), Krishi Vigyan Kendra, Ujha (Panipat), \\ CCS Haryana Agricultural University, India \\ ${ }^{3}$ DES (Soil Science), Krishi Vigyan Kendra, Ujha (Panipat), \\ CCS Haryana Agricultural University, India \\ ${ }^{4}$ DES (Ag. Engineering), Krishi Vigyan Kendra, Ujha (Panipat), \\ CCS Haryana Agricultural University, India \\ ${ }^{5}$ TA- Extension Education, Krishi Vigyan Kendra, Ujha (Panipat), \\ CCS Haryana Agricultural University, India \\ *Corresponding author
}

\begin{tabular}{|l|}
\hline Ke y w o r d s \\
$\begin{array}{l}\text { Crop residue } \\
\text { management, } \\
\text { Information } \\
\text { education } \\
\text { communication, } \\
\text { KVK Panipat }\end{array}$ \\
\hline Article Info \\
\hline $\begin{array}{l}\text { Accepted: } \\
\text { 26 June } 2019 \\
\text { Available Online: } \\
\text { 10 July } 2019\end{array}$ \\
\hline
\end{tabular}

\section{A B S T R A C T}

Food grain in India continue to be main pillar of food security and out of various crops grown, rice, wheat and pulses are still part of the staple diet of most of the rural population. Out of the various crops grown, rice, wheat and sugarcane are prone to crop residue burning. These crops are preferred by farmers since they provide higher economic return, as compared to other crops. Under the situation, appropriate package of technical intervention for crop residues management through information education communication and imparting knowledge to the end user i.e. farmers remained demand of the current era and futuristic approach. Since the crop residue management is long term process, accordingly the usage of information education communication was made and observed it impact along with the challenges faced. Through the usage of information education communication and imparting knowledge to the targeted farmers, the area of burning in the periphery of Panipat district was minimum among different districts of the Haryana state, however still the various challenges are to be managed in integrated manner in the future also. Nexus thinking will promote higher level of integration and higher level of stakeholder involvement to provide the supporting platform for solving the issue of crop residue management. 


\section{Introduction}

India being an agriculture dominant country produces million tonnes of residue annually. These residues are used as animal feed, for thatching of homes, and as source of domestic and industrial fuel. The larger portion of the unused residue is burnt in the field primarily to clear the leftover straw and stubbles after the harvest. Non availability of labour, high cost of residue removal from the field and increasing use of combines in harvesting the crops are main reasons behind burning of crop residues in the fields. Burning of crops residues causes environmental pollution, hazardous to human health, produces greenhouse gases causing global warming and results in loss of plants nutrients. It is a paradox that burning of crop residues and scarcity of fodder coexists in this country, leading to significant increase in prices of fodder in recent years. The purpose of information education communication (IEC) and imparting the knowledge of KVK Panipat fraternity to the farming community in agriculture is an important asset to bridge the gap between the potential income / output and average income / output in integrated manner. Information education and communication in agriculture programme aims to increase awareness, change attitudes and bring about a change in specific behavior. IEC means sharing information and ideas in a way that is culturally sensitive and acceptable to the community, using appropriate channels, messages and methods. It is therefore broader than developing agriculture education materials, because it includes the process of communication and building social networks for communicating information. IEC interventions involved the active participation of the target farmers and adopted villages, methods and techniques that are familiar to their world view. Information education and communication acts as an important tool in agriculture promotion for creating supportive environments and strengthening community action, in addition to playing an important role in changing behavior.

\section{Materials and Methods}

Haryana State is divided into four administrative Divisions, namely Ambala, Rohtak, Hisar and Gurgaon. Rohtak Division extended over Karnal, Panipat, Sonipat, Rohtak and Jhajjar districts. Panipat district covers 186 villages (176 inhabited and 10 as uninhabited) covering an area of 1268 square km (Fig. 1).

The Work Participation Rate (WPR) of Panipat district is 34.2 per cent in comparison to 35.2 per cent of the State.

The percentage of Cultivators to Total Workers in the district is 17.5 per cent whereas during 2001 it was 23.4 per cent.

The percentage of Agricultural labourers to Total Workers in the district is 15.1 per cent whereas during 2001 it was 14.4 per cent.

The percentage of Household Industry Workers to Total Workers in Panipat district is 3.8 per cent in comparison to 2.9 per cent of Haryana.

The percentage of other Workers to Total Workers in the district is 63.5 per cent in comparison to 52.1 per cent of Haryana.

(censusindia.gov.in)

In Panipat districts the residues of rice are not used commonly as cattle feed, and accordingly lead to the compelled circumstances of burning option. There are some other reasons also behind intentional burning of crop residues. These include clearing of fields, soil fertility enhancement, and pest and pasture management. On farm burning traditionally 
provides a fast way to clear the fields off the residual biomass, thus, facilitating land preparation and sowing / planting. It also provides a fast way of controlling weeds, insects and diseases, both by eliminating them directly or by altering their natural habitat. On-farm burning is also perceived to boost soil fertility.

Therefore, appropriate management of crop residues assumes a great significance. Keeping in view of the above significance KVK Panipat specifically adopted two villages viz., Urlana, Kaith and the efforts were made to develop conservation agriculture based crop management technologies which are more resource efficient than the conventional practices. Both interpersonal communication and mass communication types of IEC were involved.

\section{Results and Discussion}

The conservation agriculture practices made efficient use of crop residues. Through Information Education Communication (IEC), its aids and knowledge of KVK Panipat fraternity, attempts were made towards identification of the competing uses of crop residues and suggested their management options gainfully (Table 1). The resource conservation technologies (RCTs) involved no or minimum tillage, direct seeding, bed planting and crop diversification with innovations in residues management as feasible alternatives to the conventional practices. The adopted villages acted as a mirror for the others regarding utilization of the crop residues for livestock feed, composting, power generation, biofuel production and mushroom cultivation besides several other uses like thatching, mat-making and toy making. With the adoption of the IEC, the RCTs with innovations in residue management avoid straw burning, improve soil organic $\mathrm{C}$, enhanced input efficiency.
Earlier sowing of a crop in the presence of residues of preceding crop was a problem. But the new variants of zero till-seed-cumfertilizer drill / planters such as Happy Seeder, Turbo Seeder and rotary disc drill for direct drilling of seeds even in the presence of surface residues are very useful for managing crop residues for conserving moisture and nutrients as well as controlling weeds in addition to moderating soil temperature. KVK Panipat has also conducted experiments regarding incorporation of crop residues into soil or retention on the surface to examine the positive influences on physical, chemical and biological properties of soil and the microflora has also been examined under the different treatment. Yield response with residues management varied with soil characteristics, climate, cropping patterns, and level of management skills. Higher yields with crop residues application resulted from increased infiltration and improved soil properties, increased soil organic matter. Incorporation of crop residues in conservation agriculture had direct and indirect effects on pests. Lower soil temperature and higher soil moisture contents under crop residues had affected pest infestation. Indirectly, residues changed the type and density of weeds, which in turn influence insects and natural enemies.

In general, the population of termites increased under reduced tillage. Non-judicious application of pesticides under such situations disrupted the ecosystem and cause apprehension of pest outbreaks. Therefore, the adoption of integrated pest management required to be one of the necessary component of a conservation agriculture system. Through the usage of IEC in crop residue management, burning of the residues was discouraged and utilized gainfully for conservation agriculture in improving soil health and reducing environmental pollution with the logic that some amount of residues will leads towards beneficial aspects by recycling in to the soil. 
Now the farmers of the adopted village have started selling the paddy straw. As a source of the IEC KVK Panipat emphasized that satellite imageries are being used to estimate the amount of resides burnt on farm which acted as one of the psychological apprehension to prevent the burning of the residues. The research vision has been taken into consideration regarding development of crop varieties to produce more root biomass to improve the natural soil resource base, developing simulation models for prediction of impact of conservation agriculture on crop growth, soil properties, crop yield and farm income, enhancing decomposition rate of residues for in-situ incorporation, designing new generation of log-term experiments to study the impact conservation agriculture on soil health, water and nutrient use efficiency, and ecosystems services, assessing life cycle of residue based conservation agriculture vis$\grave{a}$-vis conventional method of disposing crop residues by burning and other competing uses, developing package of practices for integrated pest management (IPM) involving crops, tillage, residues, modified planting methods and pesticides in conservation agriculture to reduce use of pesticides and minimize cost of production and environmental pollution, evaluating weed dynamics, their interference potential and suitable management practices with low-cost environment friendly herbicides in crop residue based conservation agriculture, developing more advance machinery to facilitate collection, volume reduction, transportation and application of crop residues, and sowing of the succeeding crop under a layer of residues on soil surface.

KVK Panipat organized various farm ghoshties, awareness campaign, in adopted as well as other villages of different blocks, on campus training to the farmers, five days training programme in two adopted villages viz., Kaith and Urlana, organized KisanMela at KVK Panipat campus as well as at Grain Market, also had interface / farmers scientist interaction in different villages of Panipat districts. Mobilized school students also through competition and demonstration through prabhatpheri etc.

Fig.1

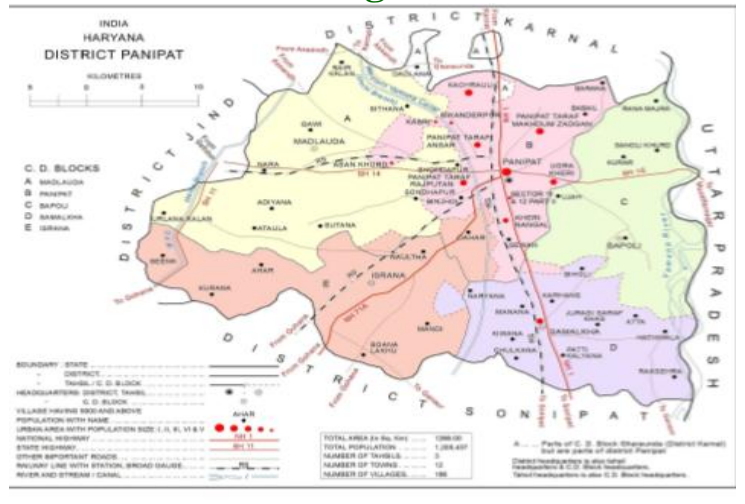

Table.1 Crop residues produced by major crops

\begin{tabular}{|l|l|}
\hline Source & Composition \\
\hline Rice & Husk, Bran \\
\hline Wheat & Bran, Straw \\
\hline Maize & Stover, Husk, Skins \\
\hline Millet & Stover \\
\hline Sugarcane & Sugarcane tops, bagasse, Molasses \\
\hline
\end{tabular}


KVK Panipat also organized capacity building of farmers on crop residue management and conservation agriculture. Through IEC in CRM, unemployed youths were encouraged to take custom hiring of conservation agriculture machineries as a profession. Through the usage of IEC, KVK Panipat campus stake holder meetings were also convened at different locations. The movement of soil and water analysis was also carried out for proper monitoring of crop residues retention / burning and its impact on soil health. The awareness campaign among the farmers was very useful for minimizing the burning of crop residues in Panipat district by overcoming the constraints to make conservation agriculture as success. Innovators played important role in bringing ideas from their knowledge in to the community who were willing to take risks, adventurous, able to cope with uncertainty and to accept occasional setbacks and require little time to be motivated. The sequence of the process of understanding the crop burning issues, looking for potential solutions, and implementation the solutions, seem very logical and the usage of information education communication has been found as one of the better alternatives for implementation of the technological interventions. Still it is felt that the crop residue management is challenging task of ensuring food security for the most populous country with one of the largest malnourished population.

\section{Constraints observed relevant to crop residues with conservation agriculture system}

A series of challenges has been observed via., difficulties in sowing and application of fertilizer and pesticides, and problems of pest infestation. Weed control is another bottle neck especially in the rice wheat system. The excessive use of chemical herbicides will not be desirable option for healthy environment. Nutrient management becomes complex because of higher residues levels and reduced options for application of nutrients. Further it required additional management skills, apprehension of lower crop yields and / or economic returns, negative attitudes or perceptions, and institutional constrains because the farmers have strong preferences for clean and good looking tiller fields vis-avis untilled shabby looking fields.

\section{References}

censusindia.gov.in/2011census/dchb/0607_P ART_B_DCHB_PANIPAT.pdf

\section{How to cite this article:}

Kushal Raj, Rajbir Garg, Dev Raj, Sundeep Antil and Satpal Singh. 2019. Impact of Information Education Communication (IEC) and Knowledge of KVK Panipat Fraternity for Crop Residue Management in Periphery of District Panipat (Haryana). Int.J.Curr.Microbiol.App.Sci. 8(07): 2937-2941. doi: https://doi.org/10.20546/ijcmas.2019.807.364 